\title{
MIGRATION WITHIN THE ANNUAL CYCLE: SPECIES, SEX AND AGE DIFFERENCES
}

\author{
Ian Newton, Centre for Ecology \& Hydrology, Benson Lane, Crowmarsh \\ Gifford, Wallingford, OX10 8BB, United Kingdom. Email: ine@ ceh.ac.uk
}

\begin{abstract}
The three main energy-demanding events in the yearly cycles of birds breeding, moult and migration - tend to occur at different times of year from one another, with minimal overlap. The sequence in which these various events occur varies according to the ecological conditions (including those encountered during migration) in which particular populations live, and in general moult is more variable in timing than other events. Some migratory birds moult in their breeding areas after nesting is over; others moult at a staging area on migration; while others moult in winter quarters. Yet others show a split moult, replacing part of their plumage in one place and part in another, moult usually being arrested during the intervening migration. Split moults are often associated with split migrations, as the birds pause for several weeks on their journeys to replace their feathers. Different variants in these patterns occur in different geographical populations of the same species. Some types of birds overlap breeding and moult, and some also overlap moult and migration, especially body moult which can occur without reducing flight efficiency. A few bird species, with short breeding cycles, have been found to nest in two different areas in a single year, separated by migration. In species in which the young are raised by only one parent, the other parent is able to begin post-breeding moult or migration at a much earlier date. In species in which individuals do not breed in their early years of life, moults and migrations are shifted into the more favourable period which in older birds is occupied by breeding. The main message of this review is the huge variation that occurs in the annual cycles of birds, in the timing and duration of different processes, the sequence in which they occur, and the degree of overlap between them. Variations occur not only between species and populations, but also between sex and age-groups within the same population. It is suggested that many species remain in a state of suspended readiness for breeding, moult or migration, and can undertake any of these processes over a greater part of the year than that in which they are normally expressed. Two or more of these processes can remain in this state of readiness simultaneously, enabling the bird to suppress, advance or delay a particular process, according to the conditions in which it finds itself.
\end{abstract}


Keywords Annual cycle.Breeding.Deferred maturity.Itinerant breeding.Moult.Migration.Moult migration.Pre-laying exodus.Seasonality

\section{Introduction}

Most birds live in seasonal environments, where day-lengths, weather and foodsupplies change in a fairly predictable manner within the year, and consistently from year to year. Under these circumstances, birds are likely to experience selection pressure to accomplish their annual cycle events at favourable times, and in a particular order to fit with changing conditions. In this paper, I explore how the annual cycles of birds vary according to the annual pattern of environmental conditions they experience, and how migration integrates with the other major events, namely breeding and moult (the period of feather replacement). I shall not be concerned with the endogenous circannual rhythms that may underlie these annual cycles, nor with the photoperiodic and other environmental cues that fine-tune their timing (for reviews of these aspects, see Gwinner 1986, Berthold 1993, Noskov et al. 1999, Wingfield 2005, Newton 2008).

The main sources of information for this paper include The Handbook of Birds of Europe, the Middle East and North Africa (Cramp \& Simmons 1977, 1980, 1983, Cramp 1985, 1988, 1992, Cramp \& Perrins 1993, 1994a, 1994b), together with the reviews of moult timing by Stresemann \& Stresemann (1966), Jenni \& Winkler (1994) and Kjellén (1994), and other sources listed in the text below. Annual cycles as a whole have been discussed by Wingfield (2005, 2008), and explored using mathematical models by McNamara \& Houston (2008) and Barta et al. (2008). My indebtedness to these earlier reviews will become evident below.

\section{The main events in annual cycles}

At their simplest, the annual cycles of birds are made up of 2-3 main processes: breeding, moult and (in migratory species only) migration. Partly because all three processes require extra nutrition above that required for everyday maintenance, they are best accomplished at different times of year. In any case, breeding requires that birds remain in fixed localities to tend their eggs and chicks, so is incompatible with migration. Moult can also reduce flight efficiency, so the advantage of not moulting 
the large wing feathers during migration is obvious. These paradigms are well acknowledged and generally accepted.

In terms of food needs, breeding is probably the most demanding event in the annual cycle of most birds. Not only do individuals have to collect more food on a day-to-day basis than they need for self maintenance, but many also have to provide specific types of food for their offspring at the time it is needed. As long appreciated, reproduction generally occurs during the season when food suitable for the young is most plentiful (Lack 1954). Other events of the annual cycle are then fitted around breeding. Most birds have only one breeding season per year, but some tropical species in regions with two distinct wet seasons can have two distinct breeding seasons each year, between which they may moult. Within a breeding season, most species raise only one brood, but those with short breeding cycles, such as many passerines, can often cram in two or more broods in quick succession.

The term migration in birds is usually applied to the return journeys that many individuals make each year between geographically separated breeding and wintering areas. The two separate journeys are usually broken by more sedentary periods in summer (breeding) and winter (non-breeding) quarters. This pattern is not invariable, however, for some bird species seem to be on migration continually or on-and-off for almost all the time they are away from their nesting areas, as evident, for example, in various pelagic species whose movements have been followed by use of tracking devices (for Sooty Shearwater Puffinus griseus see Shaffer et al. 2006; for Manx Shearwater Puffinus puffinus see Guilford et al. 2009). The same holds for some landbird species, such as Lesser Spotted Eagle Aquila pomarina, which follow rain-belts in their wintering areas to exploit the foods that develop temporarily under wet conditions (Meyburg et al. 1995, Meyburg et al. 2004). The outward and return migrations of such species could be separated arbitrarily if need be at the furthest point reached from breeding areas.

Most migratory birds, before each stage of a journey, accumulate fat and other body reserves to fuel the flight (Lindstrom \& Piersma 1993, Newton 2008). These reserves are greatest in species which make long non-stop flights over sea or other hostile substrate, with some species doubling their weights beforehand. So in these species 
migratory fattening represents another time of great food demand, and often of specific nutritional needs (Bairlein 2003), but extended over shorter periods than breeding.

The spring journey, it may be assumed, occurs at a time that will allow the birds to reach their breeding areas in time to exploit the seasonal food peak on which they breed. In fact, many birds seem to arrive in their breeding areas as soon as food appears in sufficient quantity, and their survival there becomes possible. Autumn migration, which occurs under a declining food-supply, is presumably timed so that birds leave their breeding areas before their continued survival there becomes jeopardised. These assumptions on the timing of migration are consistent with observational data, but are hard to test rigorously, although it is clear that when migrants encounter unseasonable cold at migration times, reducing their food supplies, they can suffer heavy mortality (Newton 2007).

The moult is the most variable component in its timing within the annual cycle, as it may occur in different species either in breeding areas, wintering areas, at stopover sites on migration, or in more than one of these areas. It seems that its timing is less crucial than that of breeding and migration. Nevertheless, it is an essential process with particular nutritional demands that is repeated through the life of the individual. Once feathers are formed, they become attached dead structures in which damaged parts cannot be repaired. They deteriorate through time mainly through the action of mechanical wear and sunlight (and also through feather-eating mites and bacteria), and must therefore be renewed periodically. During a moult, feathers are replaced sequentially, in consistent order, so that body insulation and (in most birds) flight is maintained throughout. Many birds moult only once per year, others twice. A moult may be complete, involving body, wing and tail feathers, or involve body (insulative) feathers alone (often associated with a change in colour from drab winter plumage to brighter breeding plumage). The keratin of which feathers are made consists of sulphur amino acids which are relatively scarce in most bird foods, so some birds may have to eat more protein than usual during moult just to get enough of these sulphur compounds. Moult also involves widespread internal tissue regeneration (including bone), and requires extra energy for the chemical processes involved, as well as to compensate for extra heat loss and reduced flight powers (Murphy 1999). 
Because reproduction, moult and migration all have extra nutritional needs, and in many birds occur at mainly different seasons, they are perhaps best considered, not in isolation from one another, but as an integrated whole. In addition, many birds show a quiescent period in winter, during which they are not breeding, moulting or migrating. Outwardly, they seem to be doing little except eating and surviving, but inwardly they may be undergoing some physiological change, such as growing gonads in preparation for breeding at a later date. Not all species show this quiescent stage, however, as they pass without obvious break from one major process ${ }^{1}$ to another (Newton 2008).

\section{Duration of migration}

Migration might impinge on other parts of the annual cycle in two main ways: first by its duration, which could restrict the time available for breeding and moult, and second by its route, which influences the pattern of environmental conditions to which the bird is exposed through the year. In many species, migration can extend across the equator from one hemisphere to another, exposing participants to 'summer' conditions year round.

In non-migrants, by definition, migration is omitted altogether from the entire lifespan, and thus differs from reproduction and moult. And among migratory bird species, migration varies in duration more than any other event in the annual cycle. Some birds can accomplish an entire one way journey in less than one day, as exemplified by the radio-tagged Bald Eagle Haliaetus leucocephalus which flew 435 $\mathrm{km}$ between its wintering site in Michigan and its nesting place in Ontario (Grubb et al. 1994). If this bird spent the same time on its autumn journey, it would have

\footnotetext{
${ }^{1}$ Wingfield (2005) and others called the different annual cycle processes of birds 'life history stages'. This term is usually used for the once-only stages that animals pass through during their development: in the case of birds, the egg, chick, juvenile and adult stages. When the same term is applied also to the annual cycle events of birds and other long-lived organisms, these events (=life history stages) are repeatable each year through the adult life span.
} 
devoted less than two days per year to migration. In contrast, ring recoveries suggest that some small passerines that travel long distances between Europe and southern Africa can spend more than half of every year on migration (including flights and stopovers). The more precise information available for satellite-tracked birds indicates that some long-distance storks spent up to $59 \%$ of the year on migration, and some long distance raptors up to $42 \%$ (Newton 2008). In general among birds, the duration of migration depends primarily on the length of the journey, and short distance migrants that migrate within Europe typically take 4-6 weeks over their autumn journeys, and long distance migrants, travelling between Europe and Africa,typically take 8-12 weeks (Newton 2008).

Nevertheless, some birds cover huge distances rapidly in non-stop flight, especially when crossing hostile terrain. An extreme is shown by the Bar-tailed Godwits Limosa lapponica that migrate non-stop over the Pacific from Alaska to New Zealand, coving the $11,000 \mathrm{~km}$ in less than ten days, although this does not include the long period spent feeding beforehand to build up the necessary body reserves (Gill et al. 2009). In addition, use of tracking devices has shown that, outside the breeding season, some pelagic seabirds seem to spend almost their entire lives on the move, in the process covering distances exceeding $60,000 \mathrm{~km}$, although they may pause for periods in areas of rich food supplies (for Sooty Shearwater see Shaffer et al. 2006, for Manx Shearwater see Guilford et al. 2009).

\section{Major variants in the sequence of annual cycle events}

The annual cycles of birds, in which different events occur at different times of year, can be regarded as an adaptation to climatic seasonality. Comparing species, however, major events vary in their timing and duration, in the sequence in which they occur, and in the extent to which they overlap. At least eight different sequences of events occur commonly among different European bird populations and others less commonly, depending on the particular ecological conditions to which each population is exposed (Figure 1). Because the most variable component within the annual cycle is the moult, most variants involve the positioning of this process. In general, residents and short-distance migrants of many species moult in summer quarters after breeding but before migration (Figure 1, sequence 1). Long-distance migrants moult either in late summer in the breeding area (as in sequence 1), in 
autumn at a migratory staging area (sequence 2) or in winter quarters (sequence 3 ) (Bensch et al. 1991, Jenni \& Winkler 1994, Kjellén 1994, Newton 2008). Moulting in winter quarters is widespread among northern hemisphere species, such as Barn Swallows Hirundo rustica, which spend their non-breeding period in the southern hemisphere, where the seasons are reversed (the southern summer coinciding with the northern winter). Less constrained by time, they also spread the moult over a longer period than species that moult in their breeding areas. Among passerines that postpone their post-nuptial moult for winter quarters, most of those that remain in the dry northern tropics of Africa moult during September-December, while food is still plentiful there, while most of those that move on to equatorial and southern Africa moult during December-April (Jones 1995).

In many other migratory species, the moult occurs partly in one area and partly in another, separated by migration. The moult can be split between the breeding area and wintering area (sequence 4), between the breeding area and a staging area (sequence 5 ), or between a staging and wintering area (sequence 6). The moult normally stops during migration, so that the bird can fly with a full set of flight feathers, some new and others old. The bird resumes the second part of moult wherever it left off in the first part (with few exceptions). In the last two of these patterns (sequences 5 and 6), a split moult is associated with a split migration, each involving separate periods of fat deposition. In other (mostly large) species, split moults are associated with breeding (as moult stops temporarily during chick feeding), or with periods of winter food shortage. Moreover, in some species in which moult is normally split between two areas, there is considerable individual variation, and occasional individuals may split their moults between three areas, especially those that are late in leaving their breeding areas.

It seems from these various patterns that some events in the annual cycles of birds are constrained by the timing of others, breeding taking precedence in timing over other events, and migration over moult. Moreover, while some migratory species have a single split moult, replacing their feathers once but in two bouts, other species have two separate moults, replacing the same feathers twice in one year. One moult occurs either before or after autumn migration (the post-nuptial or pre-basic moult), and the other before and during spring migration (the pre-nuptial or pre-alternate moult) 
(sequences 7 and 8). In most twice-yearly moulting species, the autumn post-nuptial moult is complete and the spring pre-nuptial moult is partial, involving body feathers only (and sometimes a few tertial, secondary, primary or tail feathers). However, in a small proportion of species that moult twice each year, such as the Willow Warbler Phylloscopus trochilus, both moults are complete, involving the replacement of both body and wing feathers; while in others, such as the Red-backed Shrike Lanius collurio, the post-nuptial moult is partial and the pre-nuptial moult is complete. In some species with two moults per year, both plumages look the same (as in Willow Warbler), but in other species pre-nuptial moult gives rise to a special breeding plumage, more brightly coloured than the drab winter garb (as in some passerines and waders). Examples of European species that have complete and partial moults, with distinct breeding plumages, include passerines such as Yellow Wagtail Motacilla flava and Pied Flycatcher Ficedula hypoleuca, and shorebirds, such as Red Knot Calidris canutus and Bar-tailed Godwit Limosa lapponica.

Pre-nuptial moults of the body feathers occur in many species of waders, and usually overlap with spring migration. There is also great variability in timing and extent, and among a flock of shorebirds on stopover, all variants can be seen from some birds in almost full winter plumage to others in almost full summer plumage. Many photographs published in the popular ornithological literature attest to this fact, also well known to bird-watchers. In diving and dabbling ducks, the pre-nuptial moult (mainly body feathers) begins a few weeks after the post-nuptial moult (complete). In consequence, drakes are in dull 'eclipse' plumage (equivalent to winter plumage) for only a few weeks each year and in bright breeding plumage for most of the year (Cramp \& Simmons 1977, Bluhm 1988). In association with this pattern, many species of ducks form pairs while in winter quarters, whereas most other birds pair up in breeding areas.

There can be no doubt that the different annual cycle patterns are linked to migratory behaviour. All residents and short distance migrants among passerines moult on their breeding areas before migrating. Some long-distance migrants show the same pattern, but others account for all the examples of split moults, and moults on wintering areas. Moreover, among the long distance migrants that moult in wintering areas, the 
juveniles replace all their feathers, including flight feathers, whereas the juveniles of most short distance migrants replace only their body feathers during their first year.

The various generalisations described above apply mainly to small or medium-sized birds, in which moult occurs as a distinct event in the annual cycle, typically lasting 23 months (Figure 1). In many species, moult, breeding and migration each occupy short enough periods that they can all be fitted within a year without overlap, and often with a quiescent period as well. In some large birds, however, such as vultures and albatrosses, breeding cycles and moult take so long that they cannot both be fitted within a calendar year without overlapping, and in some such species moult may also overlap with migration, especially body moult which does not reduce flight efficiency (Stresemann \& Stresemann 1966).

In most raptors, moult begins during incubation (earlier in females than males) and overlaps with much of the breeding cycle, although it may be arrested during chick rearing (as in the Sparrowhawk Accipiter nisus, Newton \& Marquiss 1982). Smaller raptor species can normally finish their moult before the post-breeding migration, but larger ones, which take longer to grow their feathers, seem to arrest moult during migration, and continue after reaching winter quarters (as in the Osprey Pandion haliaetus and Honey Buzzard Pernis apivorus) (Kjellén 1994). In some of the largest flying birds, such as vultures, condors, storks and albatrosses, each moult cycle lasts more than a year (typically 2-4 years), including the interruptions that occur at times of food stress, such as chick-rearing. Otherwise such birds appear to moult more or less continuously, and may have two or more moult waves in the primary and secondary flight feathers at once (Stresemann \& Stresemann 1966, Rohwer 1999). In addition, some large aquatic birds, such as waterfowl and grebes, circumvent the problem of slow feather growth in a different way, by moulting all their flight feathers simultaneously (becoming temporarily flightless). The whole feather series is then replaced within the time taken to grow the longest primary (about four weeks in ducks, six weeks in geese).

Variations within species

Birds clearly show great variation between species in the sequence of events through the year, their duration and extent of overlap. Moreover, unlike a successful breeding 
attempt, moult and migration can be stopped while the bird does something else. This facility adds yet more variation to the range of annual schedules found among birds, fitting the various patterns in food availability and risk to which different migratory populations are exposed during the year. This variation in annual schedules is shown mostly in comparisons between species, but also to some extent between different geographical populations of the same species. For example, many species of birds have both non-migratory and migratory populations, breeding in different regions, so that the different populations have different numbers of components in their annual cycles. In addition, with increasing latitude, the migrations of many species lengthen, and take up more of the year, while the periods devoted to breeding and moult decline in association with the decreasing length of the favourable season. In some species, populations at lower latitudes moult in breeding areas, whereas those from higher latitudes postpone their moult for winter quarters, spreading it over a longer period. Thus, Barn Swallows in the southernmost Asian breeding areas, which are resident or short-distance migrants, moult during June-August after breeding; whereas those in the most northern breeding areas begin moulting between mid September and mid November, only after they have reached their distant wintering areas, and finish between late January and late March. At intermediate latitudes, varying proportions of Barn Swallows show a split moult, starting in breeding areas, arresting during migration, and resuming in winter quarters (Cramp 1988). Likewise, most European populations of Ringed Plovers Charadrius hiaticula moult rapidly near their breeding areas in August-September, before migrating short distances within Europe, whereas arctic-nesting birds leave their nesting areas after breeding, and postpone their moult until November-March after reaching their wintering areas in southern Africa (Stresemann \& Stresemann 1966). Other geographical variants in the timing and duration of moult occur in many other wader species, mainly in association with the latitudes at which they breed and winter (see Cramp \& Simmons 1983, Meltofte 1996, Serra 1998, 2000, Underhill 2003). An extreme example is provided by the Red Knot, in which six recognised subspecies have different migratory routes and annual schedules which include variation in the positioning of pre-nuptial and post-nuptial moults, in feather quality, and in the periods that the two plumages are worn (Buehler $\&$ Piersma 2009). Some bird species also show sex differences in the timing of moult and migration, according to their different parental roles, as discussed below (Newton 2008). 
Otherwise, individual variations in the start dates of moult and migration in the same population relate chiefly to variations in the dates they finish preceding activities. Among populations which moult in their breeding areas, adults that continue breeding later in the year than others typically start their moult and migration later, and young raised late in the year start moulting and migrating later than earlier-hatched young, sometimes also replacing fewer feathers (eg. Newton 1999, Noskov et al. 1999, Newton \& Rothery 2005, Flinks et al. 2008). It is also common for late-nesting adults to start moulting while they still have young in the nest, and to replace their feathers more rapidly or less completely than earlier moulting individuals. Similarly, latefledged juveniles start moulting at an earlier age than early hatched ones, thereby lessening the delay in their migration (Jenni \& Winkler 1994, Berthold 1993, Noskov et al. 1999, Bojarinova et al. 2008, Newton 2008). This trend was called the 'calendar effect' by Berthold (1993).

\section{Other variants of the annual cycle}

Most birds breed regularly at the same times each year, but others breed at varying times depending on the food resource, with knock-on effects on the timing of moult and movements. Given sufficient food, at least three main patterns have been described. The first involves a substantial extension of the normal breeding season, as found in Galapagos finches and others (Gibbs \& Grant 1987). The second involves a main breeding season in spring and an additional one in autumn, separated by moult, gonad regression and regrowth, as noted in the Tri-coloured Blackbird Aegalius tricolor, Pinyon Jay Gymnorhinus cyancephalus and others (Payne 1969, Ligon 1971). The third involves breeding in different months in different years, whenever food is sufficiently plentiful (often depending on irregular rainfall), as found in the Black-and-White Manakin Manacus manacus, Zebra Finch Taenopygia guttata and others (Snow 1962, Zann et al. 1995). The last pattern is also found among Common Crossbills Loxia curvirostra, dependent on the sporadic fruiting of different conifer species that provide their food (Newton 1972).

Breeding seasons split by migration

Unlike moult and migration, a single breeding cycle from egg-laying to fledging cannot be split between two separated periods. However, some species with short 
breeding cycles are able to raise successive broods in widely separated areas, by migrating between the two attempts. Among European birds, so-called itinerant breeding was first suspected in Quail Coturnix coturnix, in which females arriving in Italy in June-July, apparently to breed, showed regressing brood patches from an earlier nesting attempt, and were frequently accompanied by young no more than two months old. These young must have hatched from clutches begun in March, a date at which breeding would only have been possible further south - in North Africa. Reports of a general exodus of Quail from Tunisia in spring after breeding supported this view, and single birds ringed there in May and June were recovered 2-3 months later in Italy and Albania (Moreau 1951, Cramp \& Simmons 1980, Aebischer \& Potts 1994). Similarly, late clutches in northern Europe during August-September could have resulted partly from an influx in mid-summer of birds that had previously bred in the Mediterranean region. Quail can mature and breed at three months old, so that young produced in the southern parts of the breeding range could nest the same summer in the more northern parts, along with the adults on their second or third attempt. About half of the large numbers of Quail that bred in France in 1987 were deemed to have hatched earlier in the same year (Hémon et al. 1988).

As another example, the Common Redpoll Carduelis flammea can curtail its migration by up to several hundred kilometres to breed in southern Fennoscandia in years when the Spruce Picea abies crop there is good (Peiponen 1967, Götmark 1982). Once the seeds have fallen, the birds move north to their usual birch-scrub breeding areas, where they raise another brood. Such movements have not been proved by ringing, but have been inferred from the simultaneous changes in the populations of the two regions and, in particular, from the late arrival in these years of birds in the birch areas with free-flying young. In most other years, with no early nesting, only the single later brood is raised.

Eurasian Siskins Carduelis spinus may behave in a similar way, for adults and recently fledged juveniles were in several years seen migrating northeast in May-July over the Courland Spit in the southern Baltic (Payevsky 1994). Some of the adults appeared paired at the time, and many trapped females had a shrunken brood patch, signalling a recent nesting attempt. In the years 1984-1987, some 23-91\% of adult 
females trapped in late April-July had brood patches, as did 35-86\% of yearling females (total females caught $=1,230$ ). One juvenile caught in June 1959 had been ringed 25 days earlier, $760 \mathrm{~km}$ to the southwest, in Germany. While it could not be proved that the adults among these Siskins went on to breed elsewhere in the same year, they clearly had enough time to do so. Breeding in separated regions within one year probably also occurs in Common Crossbills which, given appropriate seed crops, can breed in spring and again in autumn, separated by moult and migration (Newton 1972). Other examples of species of Fringillidae and Turdidae in which individuals are likely to have bred in two separate areas in the same year were mentioned by Noskov et al. (1999).

Among shorebirds, females of some species move on to breed elsewhere after laying a clutch of eggs, leaving incubation and chick care to their mates. Examples include the Eurasian Dotterel Charadrius morinellus, in which, after laying one clutch in Scotland, some females move on to Norway to lay another clutch for a different male. Some male Dotterels also move long distances during a breeding season, nesting first in Scotland and then, after nest failure, moving on for another attempt in Norway (Whitfield 2002). These movements have been confirmed by ringing.

In the above examples of split breeding seasons, birds bred first in the south of the breeding range and later in the year further north, following the advance of spring. It is almost as though the birds interrupted their spring migration to breed, later moving on. A different pattern has recently been described in some North American birds, which breed first in the north of the breeding range, and then as the summer dries, move south to breed again in more southern latitudes (in western Mexico) as the summer rains begin in these areas, bringing a new flush of food (Rohwer et al. 2009). Known examples are insectivores, and include at least five species, namely the Yellow-breasted Chat Icteria vireo, Cassin's Vireo Vireo cassinii, Hooded Oriole Icterus cucullatus, Orchard Oriole Icterus spurious and Yellow-billed Cuckoo Coccyzus americanus. The successive breeding areas of these species are separated by hundreds or thousands of kilometres. The evidence is again inferential, based partly on isotope analyses of tissues which showed that individuals which appeared in Mexico to breed had recently (previous 8 days) spent time in northern breeding areas; in addition, females among these newly arrived birds had shrunken brood patches, but 
both sexes still had active gonads or showed reproductive behaviour. In these birds, it is as though autumn migration was interrupted to allow additional breeding. The first three species are thought to moult after nesting in their late summer (Mexican) breeding areas, whereas the other two delay moult until after they have reached their winter quarters further south.

So it seems that, in one species or another, all major processes in the annual cycle including breeding - can be split if it is advantageous to do so. All these migratory double breeders add an extra migration and bout of breeding into their annual cycles, with the attendant periods of physiological transition, but for none is it known what proportion of the population is involved. Nevertheless, they challenge the notion that physiological mechanisms prevent migrants from incorporating additional components into their annual cycles, either because of the time taken to change from one physiological state to another, or because of incompatibilities in the endocrine mechanisms supporting different processes (Wingfield 2005).

Split breeding seasons enable species that could raise only one brood in a given locality to become multi-brooded, providing they can raise young to independence within a relatively short period. Species with long breeding cycles and prolonged parental care would not be expected to become itinerant breeders in seasonal environments, because they could not raise more than one brood in the time available. In the absence of support from ringing, breeding in more than one area in a single year can be detected only when newly arrived adults have brood patches, recently fledged young or other signs of recent reproduction, and then proceed with a new nesting attempt. It is clearly rare or non-existent in the vast majority of well-studied European birds.

Itinerant breeding is also shown by the Red-billed Quelea Quelea quelea, which feeds on grass seeds on the African savannahs. As the rain belts spread across tropical Africa, they stimulate the growth and seeding of grasses, providing a sufficient temporary food supply to enable Queleas to breed. After raising their young, the birds move en masse, stopping again in an area where rain has recently fallen, and raise another brood (Ward 1971, Jaeger et al. 1986). Throughout the dry season, these birds subsist on dry seeds picked off the ground, but when the rains break, this seed 
suddenly germinates, thus removing the food supply. The birds then fly over the approaching rain front to areas where rain fell about two months earlier and new grass seed has already formed. This new still-green seed, and insects associated with the growing vegetation, enable the birds to breed. The birds apparently follow the rains in successive breeding attempts, each time moving some hundreds of kilometres. Within this framework, the pattern is variable from year to year, depending on regional variations in rainfall and grass seed production. Conditions suitable for rearing young do not last long in any one place, and only by periodically moving to keep in step with the slowly shifting zone of seeding grasses are individual Queleas able to raise more than one brood per year.

Three lines of evidence confirm this pattern in Quelea: (1) many females begin developing the yolks for a second clutch while still feeding the first brood, yet they do not breed again in the vicinity; (2) in those regions where colonies contain birds likely to be breeding for the second time, adults arrive in badly worn plumage, consistent with a previous nesting attempt; and (3) some birds colour-dyed in one colony were re-sighted 2-3 months later in other colonies 500 and $700 \mathrm{~km}$ away (Jaeger et al. 1986). In West and southern Africa there is time in wet years for birds to raise three broods in quick succession at different places along the rain front, and in East Africa up to five, but it remains to show whether these maxima are ever reached.

The fact that individual Quelea depart while developing eggs for the next clutch implies that the gonads do not regress during the migrations involved. The same is likely to hold for the other species discussed in this section, for their migrations need take no more than a few days out of a much longer breeding season. In physiological terms, migratory and reproductive phases overlap, in the same way that migration overlaps gonad growth and pre-nuptial moult in many shorebirds and others.

Some other birds in semi-arid regions, which breed at a particular stage in the dry-wet seasonal cycle, may also raise successive broods in places far apart. Substantial shifts in colony sites during a single season have been suspected for Eared Doves Zenaida auriculata in northeastern Brazil (Bucher 1982), White-crowned Pigeons Columba leucocephala on Hispaniola (Arendt et al. 1979), Tricolored Blackbirds Agelaius 
tricolor in California (Hamilton 1998), and Spanish Sparrows Passer hispaniolensis in various regions (Cramp \& Perrins 1994a).

The pre-laying exodus of petrels

The pre-laying exodus of petrels is a different kind of within-season movement. Once they have returned to breeding areas, re-occupied nest sites and re-established pair bonds, many procellariiform species leave their breeding areas for periods of days or weeks to feed up for egg production and incubation. In the process they may travel to foraging areas hundreds or thousands of kilometres from the nesting colonies: for example, Manx Shearwaters Puffinus puffinus fly up to 1,200 kilometres from the colony, and White-chinned Petrels Procellaria aequinoctialis more than 2,000 km (Guilford et al. 2009, Phillips et al. 2006; Table 1). These latter birds returned all the way to their wintering areas. Both sexes need reserves to get back to the colony; the female also to produce the single large egg and the male to undertake the first major incubation stint which lasts for several days or weeks, depending on species. Later in the breeding cycle, when the spring is more advanced, the birds tend to feed nearer the colony, as confirmed by use of tracking devices. Perhaps only then, later in the season during the chick-feeding period, is food sufficiently abundant near the colony.

In some procellariiform species, both sexes participate in the pre-laying exodus, travelling independently of one another, and the nesting colonies may be totally deserted for a time, while in other species the journeys are made mainly or only by females, or the females travel further (Warham 1990, Schreiber \& Burger 2002). Mean periods of absence vary between species from a few days up to around 60 days (50-80 days in Great-winged Petrel Pterodroma macroptera), presumably depending on distance travelled, as well as on feeding rates. The females usually lay the egg within a day or two after their return, whether the male is back or not, confirming that mating occurred in the pre-exodus period, up to several weeks earlier, the sperm being stored in special utero-vaginal glands in the interim (Hatch 1983). In some species the pre-laying exodus is sudden and dramatic: for example, all Short-tailed Shearwaters Puffinus tenuirostris desert the colony within a five-day period; they return equally dramatically about three weeks later, and the first eggs are laid on the night they reappear (Warham 1990). 
Feeding areas that have been identified lay in a customary migration or wintering area, so are presumably well-known to the individuals concerned. Nevertheless, it is amazing that birds may return from spring migration, remain a few weeks in their nesting places, and then migrate back to staging or wintering areas, before returning to lay an egg and proceed with a breeding attempt. The annual cycles of such species thus consist of return migration to breeding areas, a period at the nest site (involving copulation), migration to a distant feeding area, return migration to the nest site, and continuation of the breeding cycle, followed by post-breeding migration to wintering areas and moult. This schedule involves two extra migrations, and a split breeding cycle, interrupted between the pair being re-established and the egg being laid. It is probably widespread among procellariiform birds, but while some species travel to far distant foraging areas in the pre-laying exodus, others travel shorter distances, enabling them to return frequently (Warham 1990). I use the word 'migration' for these movements because in some species they are clearly much longer than the normal long-distance foraging flights undertaken during the rest of the breeding cycle, and entail a much longer period away from the nest. Similar pre-breeding exodus flights of 500-1,000 km have been recorded from some non-procellariiform species, including Brown Skuas Catharacta lonnbergi nesting on South Georgia (Phillips et al. 2007).

The pre-laying exodus provides a means by which a long breeding cycle can be accommodated within a shorter favourable season, without compromising the later stages of breeding when food needs are greater. However, it is not obvious to me why procellariiforms should adopt this strategy, rather than accumulating all the reserve shortly before returning to the colony, and then lay within a few days, as do many arctic-nesting geese. But procellariiforms differ from waterfowl in not being paired before arrival in breeding areas, so they have no opportunity to copulate before then; they also spend a much longer period at their nest sites before laying than do geese.

The moult migration of waterfowl

Another variant is the moult migration of waterfowl, in which birds travel after breeding to special areas, offering security and food, where they moult all their flight feathers simultaneously (becoming temporarily flightless), before moving on to wintering areas (Salomonsen 1968, Jehl 1990). Moult migration adds another 
component to the annual cycle. It could be regarded as similar to a moult on a staging area, already described in other species (sequence 2 in Figure 1), although in waterfowl the moulting area does not necessarily lie between the breeding and wintering areas, but in any direction from nesting areas - to the east, west, south, or even north - as in various species of geese (Salomonsen 1969, Newton 2008). Moving northward to moult may offer temporarily better feeding conditions, but it also greatly lengthens the subsequent journey to wintering areas. Moult migrations are not trivial, and while birds from some nesting populations travel up to a few hundred kilometres between nesting and moulting sites, those from other populations travel 2,000-3,000 km, sometimes forming concentrations at traditional moulting sites of tens of thousands or hundreds of thousands of individuals (Salomonsen 1969, Newton 2008).

\section{Non-annual cycles}

Some birds differ from the majority in that they show cycles that last more than a year. This applies to some large birds, such as Wandering Albatross Diomedia exulans, in which pairs take more than one year to raise a chick to independence (Warham 1990). These birds therefore lay every second year, but at about the same time of year, so the annual environmental cycle still imposes its pattern. Moult overlaps with breeding, and also lasts more than a year, but runs more rapidly in the gaps between breeding attempts. At least four other species of albatrosses breed every second year (Warham 1990). In some circumstances biennial breeding also occurs in the California Condor Gymnogyps californianus and African Crowned Eagle Stephanoaetus coronatus, but in these species annual breeding has also been recorded (Koford 1953, Brown 1966).

Other birds live in non-seasonal tropical environments, and have cycles that last less than one year. A well-studied example is the Sooty Tern Sterna fuscata nesting on equatorial islands (Ashmole 1963). In this species, a full cycle of breeding and moult lasts about 9.6 months, and birds start successive cycles one after the other in rapid succession. Each successful female therefore lays each year 2-3 months earlier than it laid in the previous year. Different females are out of phase with one another, so that within a colony birds at all stages of breeding can be found at one time. The same applies to Audubon's Shearwater Puffinus lherminieri (in which individuals lay at 9- 
month intervals) and some other seabirds on the Galapagos Islands (Snow 1965). It also applies to some land-bird species in equatorial South America where, in a semiarid area with erratic rainfall at $3^{\circ} 30^{\prime} \mathrm{N}$, eight out of ten species bred year-round, with the cycles of different individuals out of phase with one another (Miller 1954). In the Rufous-collared Sparrow Zonotrichia capensis individuals took six months to complete a cycle of breeding and moult, and again moved from one cycle to the next in swift succession (Miller 1959). This species therefore accomplishes two full cycles within each calendar year, but again different birds are out of synchrony with one another.

Yet other birds in arid regions have irregular breeding seasons governed by sporadic rainfall, which promotes the growth of fresh vegetation and invertebrate activity on which bird breeding depends. The same species may breed in different months in different years, sometimes at more than annual intervals and sometimes less, depending when it rains. The timing of moult seems to be more regular, but when rain falls, moult is arrested and breeding begins. This pattern has been described in several species, including the Zebra Finches Taenopygia guttata mentioned above (Zann et al. 1995).

\section{Sex differences in the timing of annual cycle events}

In many bird species, the sexes have different roles in parental care, and this is reflected in corresponding differences in the timing of their moults and migrations. In most species in spring, males migrate earlier and arrive in nesting areas before females (although this is an average difference, with wide overlap between the sexes). So-called protandry has been attributed to the need for territory-holding males to reach breeding areas earlier to obtain nesting territories. This view is supported by the fact that, in species which show reversed sexual roles (with the female establishing the territory and the male raising the young), females arrive before males, as recorded in the Dotterel, the three plalarope species, Spotted Sandpiper Tringa macularia and others (Myers 1981, Oring \& Lank 1982). Moreover, in many species in which the sexes differ in average spring arrival dates, they show no obvious difference in autumn departure dates (Newton 2008). 
Departure from breeding areas depends largely on when parental duties finish (even though some species may then moult before leaving). In many bird species, failed breeders leave their nesting areas earlier than successful ones, and in years of widespread breeding failure, as sometimes occur in arctic-nesting shorebirds, postbreeding migration occurs noticeably earlier than usual. In addition, in some bird species, only one sex looks after the young, which frees the other to depart at an earlier date. This is evident, for example, in most duck species in which the males play no part in parental care, and leave their breeding places (for moulting sites) up to several weeks before the females and young (Salomonsen 1968, Cramp \& Simmons 1977). Some wader species, such as Curlew Sandpiper Calidris ferruginea and Ruff Philomachus pugnax, show a similar pattern, in that the females remain until their young are full-grown, allowing the males to leave the breeding areas some weeks earlier. In other waders, such as Spotted Redshank Tringa erythropus and Wood Sandpiper Tringa glareola, the males raise the young to this stage, allowing the females to depart earlier. In yet other waders, such as Lapwing Vanellus vanellus and Black-tailed Godwit Limosa limosa, both partners help to the same stage with parental care, and the two sexes migrate at about the same time (Cramp \& Simmons 1983). In these various species, therefore, post-breeding migration dates are clearly influenced by parental roles, and preceding events in the annual cycle. The repetition of this pattern in different kinds of birds further emphasizes the link between breeding commitment, and the timing of moult and migration. The fact that, on finishing breeding commitments, individuals of these various species switch immediately to the next event in the annual cycle - whether moult or migration - is presumably of advantage, because it brings that event forward to a more favourable time of year, enabling the bird to accomplish its moult or migration in better conditions or in less hurry.

\section{Age differences in migration dates}

Adult-juvenile differences in mean migration dates occur in a wide range of bird species, from songbirds to raptors and waders (Newton 2008). For example, in many species, younger breeders tend to arrive on nesting areas later than older ones of the same sex. Again, however, much bigger differences occur in mean autumn departure dates. Among songbirds, the pattern seems to depend on whether a moult is completed in breeding areas before the start of migration (in which case the young 
leave first), or whether moult is suspended or delayed and migration occurs immediately after breeding (in which case the adults leave first). Most species that moult completely before autumn migration are short-distance or partial migrants, while most of those that arrest or delay moult are long-distance migrants that winter in the tropics or beyond. In short-distance migrants, juveniles leave first, presumably because they replace only their body feathers, a process which takes less time than the adults take to replace their entire plumage, including their flight feathers. In contrast, in species that suspend or postpone moult, the adults can leave their nesting areas soon after their last young are independent, while the young themselves take another week or more before they are ready to embark on their first migration. This dichotomy according to the place of moult held in 54 passerine and near-passerine species (including European and North American) for which relevant data on moult and migration were available (Newton 2008). The Common Cuckoo Cuculus canorus is an extreme example, for the adults leave their breeding areas for Africa before their last young, reared by other species, have even left the nest, giving a difference in mean departure dates between adults and juveniles of about one month (Wyllie 1981). Both age groups moult in their African winter quarters.

Similar departure patterns are seen in some larger non-passerines, including raptors. In short-distance and partial migrants that finish moult before migrating, such as the Common Kestrel Falco tinnunculus, juveniles leave the breeding areas earlier, on average, than adults. But in most long-distance migrants that suspend moult and migrate immediately after breeding, such as the Osprey Pandion haliaetus and Honey Buzzard Pernis apivorus, adults tend to leave before juveniles, departing as soon as their young are independent but still gaining the body reserves and experience necessary to undertake migration. In all these raptors, the juveniles do not moult at all in their first autumn of life, but retain their juvenile plumage (acquired in the nest) for another year.

After nesting in the arctic, adult waders usually leave their breeding areas well before the juveniles, and moult at a migratory staging site or in winter quarters. In some species, the juveniles also progress more slowly on migration, taking longer and more frequent stops, or less direct migration routes (Evans \& Davidson 1990). Hence, in all these species from different taxonomic groups, whether adults or juveniles depart first 
on autumn migration seems to be linked to whether or not they migrate immediately after breeding, and where and when they moult. The pressures are somewhat different between juveniles and adults because, whereas the juveniles have a short body moult (or in some species no moult), the adults have a longer complete moult, including flight feathers. Again, the differences in timing between age groups are apparent chiefly in mean values, for at the population level the overlap between adults and juveniles is often considerable. But these findings again reveal how the timing of any one event in the annual cycle is influenced by the timing of the preceding events, in this instance producing a difference between the mean migration dates of adults and juveniles.

Deferred maturity and modified annual cycles

The effects of relaxation in constraints on timing are also apparent among the immatures of species which do not breed in their first year of life, freeing them to moult and migrate at different dates from adults. In some such species, individuals migrate from the breeding range in their first autumn, and do not return in the next spring, but only in a later one, when they are two or more years old. These young birds either remain in their 'wintering' areas year-round over one or more years, or they may return only part way towards the breeding areas. Alternatively, they may visit the breeding areas for only a small part of the season, migrating later in spring and earlier in autumn than older birds. Unconstrained by the needs of breeding, they perform both migrations in less hurry than the breeding adults, and at a more favourable time. They also moult earlier than the breeding adults, also at a more favourable time. Such patterns are shown by various raptors, seabirds, waders and others in which individuals do not breed until they are several years of age (Newton 2008).

In some first-year shorebirds that stay in 'wintering areas', pre-nuptial moult and fattening are much delayed, sometimes into July, too late for the birds to breed that year (McNeil et al. 1994). Other first-year individuals show no sign of pre-migratory fat deposition or spring moult into breeding plumage, but remain in well-worn plumage until they moult in late summer into adult winter plumage. This was apparent, for example, among first-year Curlew Sandpipers in South Africa, and among Turnstones Arenaria interpres in Scotland which stayed in their wintering 
places, while adults wintering in the same places began to moult, accumulated body fat and left in spring in the usual manner (Elliott et al. 1976, Metcalfe \& Furness 1984). Although the birds that stay year-round in 'wintering areas' do not always undergo a spring moult into summer plumage, they moult in late summer into fresh winter plumage up to several weeks earlier than do adults returning from breeding areas. For example, Turnstones spending the summer in England moulted seven weeks earlier than returning adults (Branson et al. 1979). As with migratory timing, they provide an example of birds moulting at a more favourable time of year when not constrained by breeding.

Over-summering in 'winter' quarters has been found among the juveniles from at least 15 taxonomic families of birds, being best known among raptors, herons, shorebirds and various seabirds. As they get older, increasing numbers of seabirds begin to return to nesting colonies during summer, 'prospecting' for nest-sites. At a colony of Common Terns Sterna hirundo in Germany, fledglings were marked with transponders, allowing their subsequent return to be registered automatically (Dittman \& Becker 2003). Most individuals showed up at the colony for the first time as two-year-olds, and remained as 'prospectors' for a year or more before starting to breed. Prospectors arrived later than breeders (too late to breed), and first-time breeders arrived, on average, 17 days later than experienced breeders. The arrival dates of Common Terns became progressively earlier up to several years of age, and on average, males arrived earlier than females. The successive arrivals of established breeders, new breeders and then prospectors was spread over several weeks each year, as was their subsequent departure. Similar patterns of arrival have been recorded in Manx Shearwaters, Razorbills Alco torda, Common Guillemots Uria aalge and others (Perrins et al. 1973, Lloyd \& Perrins 1977, Halley et al. 1995).

Similar age-related trends in the timing of migration have also been noted in raptors. For example, in the various eagle species that migrate through Israel each spring, the age groups pass in order of oldest first to youngest last, again spread over a period of several weeks (Shirihai et al. 2000). Among some radio-tagged Lesser Spotted Eagles and Steppe Eagles Aquila rapax, immature birds migrated later and more slowly than adults, arriving in breeding areas 6-10 weeks later (Meyburg \& Meyburg 1999). As in seabirds, because these immature raptors make no attempt to nest, they suffer no 
obvious penalty by arriving later and leaving earlier than older birds, and may benefit from migrating at a better time of year.

Similar patterns of (a) pre-breeding birds over-summering in 'wintering' areas, (b) returning part way towards breeding areas, or (c) returning to breeding areas for a shorter period than nesting adults, also occur in some waders. From wintering areas, immature birds left in increasing proportion, and progressively earlier each year as they grew older, as shown in individually marked Oystercatchers Haematopus ostralegus, Grey Plovers Pluvialis squatarola and Avocets Recurvirostra avosetta (Goss-Custard et al. 1982, Evans \& Davidson 1990, Hötker 2002). In one wintering population of Oystercatchers in southwest England, individuals began to return to breeding areas from about the fourth summer on, but males did not begin to breed until ages 5-8 years and females until 3-6 years (Goss-Custard et al. 1982).

Comparing different wader species, a significantly greater tendency to over-summer in winter quarters occurs in those populations with the longest migratory flights that winter furthest from their breeding range (Summers et al. 1995, Hockey et al. 1998). Such latitudinal trends are also apparent in different populations of the same species, such as the Ringed Plover (Evans \& Davidson 1990), and the same holds for some gulls, cormorants and others. Perhaps the longer journeys tip the balance in young birds in favour of staying rather than returning to the breeding range. In waders, oversummering in winter quarters is also significantly more frequent in species occupying coastal habitats in the non-breeding season than in those found at freshwater wetlands (Rogers 2006).

\section{Discussion}

The overall message of this paper is that birds show great flexibility in their annual cycles - in the sequence, duration and overlap between different main processes according to their phylogeny, the environments in which they live, and where their migrations take them. The fact that moult and migration can be temporally halted while some other process occurs adds further variation, as does the ability of some species to migrate between successive broods within a breeding season. So in thinking about the physiological control of annual cycles, we need to bear in mind that there is no single set pattern, or just a few set patterns; almost any sequence occurs in one 
population or another. Much seems to depend on the temporal-spatial pattern of environmental/feeding conditions to which the birds are exposed on their annual journeys (see also Barta et al. 2008).

Another important point is that the broad patterns in the annual cycles of birds are apparently inherent, as the same cycles persist in captivity, and hybrids between birds from different populations show patterns of breeding, moult and migratory activity which are intermediate between those of their parents (for passerines see Berthold 1993, 1996, Pulido \& Berthold 2003 and Helm et al. 2005, and for waterfowl see Murton \& Westwood 1977). Although the sequence of life history stages appears to be innate, the rate of transition from one stage to another can evidently be modified by local conditions, and particularly by the stage at which breeding ends (whether by nest failure or success). If breeding is omitted or ends prematurely because of egg or chick loss, the bird can switch rapidly to the next stage, whether moult or migration.

The duration of each component in the annual cycle can be measured directly from field observations. Comparing species, breeding can take anything from about five weeks in some small passerines to more than a year in large albatrosses (giving more than 12-fold variation between species), a complete moult takes from about a month in some small passerines to 2-4 years in some large eagles and albatrosses (say up to 48-fold variation), while in migrants, journey times can take anything from less than two days per year to around 215 days (108-fold variation, Newton 2008).

\section{Individual variations}

Special interest attaches to partial migrants, in which two genotypes (one which migrates every year and the other does not) may persist side by side in the same population (obligate partial migrants), or in which individuals have the ability to include or exclude the migratory component, depending on conditions at the time (facultative partial migrants). This latter facility enables the same individual to migrate in one year and not in another, depending on individual circumstances. In general, individual facultative migrants are more likely to undertake migrations to wintering or moulting areas in their earlier years of life than later (for passerines, see Smith \& Nilsson 1987, Schwalb 1983; for geese see Salomonsen 1968). 
A second type of age-related variation was discussed above, in which some individuals, having migrated in the first autumn to wintering areas, do not then return for one or more years (associated with deferred breeding). This again shows that individuals can vary the number of annual cycle components that are expressed each year, depending on their age and other circumstances. Other flexibility is apparent in many passerines which can vary the number of nesting attempts per year, and in Common Redpolls and others, which may breed in two separated areas in some years, but only in one area in other years.

Numbers and overlaps of components

The numbers of components that comprise an annual cycle vary from two in some non-migrants (breeding and moult, with no quiescent period) to seven in migrants that show split moults, split migrations or split breeding seasons. Presumably, however, the more components there are in the annual cycle, the less flexibility in the timing of any one component the bird might have (Wingfield 2005, 2008). For populations with more than two components, the progression of components is unidirectional, and long-lived individuals will pass through all components several times in pre-ordained manner during their lives. No component seems to be inserted out of sequence, but particular components, such as breeding or migration, can be omitted in some years. In these cases, close inspection usually reveals that reproductive systems show at least partial development, and at times of migration some degree of fattening and other preparation may also occur, whether the bird migrates or not (Wingfield 2008).

Each component has specific time needs, occurring at specific seasons, giving limits to the number that can be expressed within a year without substantial overlap. Most of the recorded overlap between different processes involves the terminal stage of one process with the developmental stage of another (Wingfield 2008). This type of overlap is frequent in passerines which may begin post-breeding moult while they are still feeding young, or begin migration before their last few primaries have reached full length.

Even greater overlap, in which two or more components are fully expressed simultaneously, is seen in many large birds which may moult while they are also breeding or migrating. It is also seen in many shorebirds and passerines which grow 
gonads and moult body feathers during spring migration. Prenuptial moult in these birds is partial, so its nutrient needs are less than those of a full moult, and being restricted to body plumage, it does not affect flight capability. Gonad growth is slow, and at this stage probably requires little in terms of daily nutrient needs. Nevertheless, in some bird species females are ready to lay eggs within a few days after arriving in nesting areas, as recorded in Quelea and others, as well as in the procellariids, some of which lay within 12 hours of returning from their pre-laying exodus (see above). Once an egg has been laid, however, migration must stop, as the bird is then tied to that locality for some weeks if the breeding attempt is to succeed. Whereas breeding (from egg-laying on) and migration are incompatible, moult can overlap with either or both of these processes, at least to some extent, as shown in many species. In addition, in some auk species, such as Common Guillemot Uria aalge, the young leave the nest at an early stage, and migrate by swimming; they are accompanied and fed by a parent en route, giving overlap between chick care and migration. Since the adults moult at this time, replacing all their flight feathers simultaneously, they can be said to overlap all three main processes - breeding, moult and migration (Newton 2008). Among birds in general, most overlaps between different annual cycle events involve moult.

In another situation, two or three components may remain in a state of partial readiness for much of the year, each sufficiently developed to be switched on or off rapidly, but with only one expressed at a time. In some bird species, which breed at different times in different years, mature gonads are maintained for prolonged periods in a constant state of readiness in preparation for the unpredictable onset of favourable conditions. This situation has been described in Zebra Finches Taeniopygia guttata, for example, which remain reproductively prepared for much of the year (Zann et al. 1995). The males retain spermatogenically active testes, and females have ovaries containing follicles in an advanced resting state until appropriate conditions arise. The birds breed in response to rainfall, which promotes the growth and seeding of grasses, the young being fed (like Quelea) mainly on the ripening seeds. From field observations, one might judge that this type of situation exists to some extent in many kinds of birds, and affects moult and migration as well as breeding. Thus moult can occur earlier than usual in birds which omit or fail in their breeding, and can itself be interrupted temporarily in conditions of food stress, as during periods of chick rearing (as in some raptors) or post-nuptial migration (as in some shorebirds). If moult is not 
totally arrested, it may be slowed (for example by reducing the numbers of feathers in growth at once), thus lessening the nutrient demand. Similarly, migration can be interrupted if the birds encounter especially good conditions, or alternatively it can be initiated in emergencies. Individuals of many species seem able to move on at any stage during the autumn and early winter if food supplies are exhausted or rendered unavailable by snow and ice (Newton 2008). Such emergency movements are likely to vary between species, and some have been given special names, such as 'eruptions' or 'weather movements'. It seems, then, that many birds are able to undertake breeding, moult or migration over a longer period each year than that in which these processes normally occur. Remaining in a state of partial readiness over a long period each year may be one way in this can be accomplished.

\section{Split breeding seasons}

Why do split breeding seasons not occur more commonly, especially in small passerines with short breeding cycles? It might be thought that many species migrating north through Eurasia or North America in spring could raise more broods by stopping and nesting at different latitudes en route than by breeding only for a short season in the north, where only one brood can be produced in the time available. The prior occupation of more southern habitat by conspecifics may be one factor preventing this. Moreover, the southern habitat usually remains suitable for further nesting after the first broods fledge, which encourages birds to stay. This is not the situation in known itinerant multi-brooded species, such as Redpolls and Quails, which settle in spring in areas that have only just become suitable and where there is no established prior population; their habitat or food supply then deteriorates so rapidly that individuals are forced to move on if they are to breed again in the same season. The Redpolls were exploiting temporarily available conifer seeds produced as cones opened, and moved on when the seed had fallen; while the Quails were exploiting the spring growth of vegetation which soon died in the summer heat, affecting insect availability. Similarly, Quelea depend for breeding on a mixture of insects and unripe grass seeds, so can stay to breed in any one area no longer than needed to raise a brood. The situation in the North American insectivores which breed first in temperate North America and then in western Mexico differs, in that western Mexico holds already-present individuals of all these species. At the time the immigrants arrive, however, fresh rains have encouraged dry deciduous forests to leaf 
out and flower, promoting a massive increase in insect food supplies. Other species, such as Painted Bunting Passerina ciris from further north, move into this area to moult, before moving on to their wintering areas further south (Thompson 1991, Rohwer et al. 2008). In these examples, individuals moved so far between successive breeding attempts that the movement could be fairly described as a migration inserted within a breeding season. At least in Quelea, fat is known to be deposited before the journey (Ward \& Jones 1977).

In birds with a split breeding season, it is unlikely that the gonads regress during the migrations involved, for these migrations seem of short duration. Moreover, in Quelea, individuals depart while developing eggs for the next clutch, laid in a different area. This gives overlap between migratory and reproductive phases, in the same way that migration overlaps gonad growth and (mainly pre-nuptial) moult in many shorebirds and others. The ability to overlap different processes can be viewed as a time-saving mechanism that adds flexibility for individuals, but raises interesting questions over the physiological control, most studies having been conducted on species with simple annual cycles in which different processes follow one another without appreciable overlap (see Wingfield 2008 for discussion of proximate controlling mechanisms).

\section{Conclusions}

1. Great variation is found in the annual cycles of birds: in the timing and duration of the different components that make up the annual cycle, in the number of components, in the sequence in which they occur, and in the degree of overlap between them. Further variation is added by the facility that some species have to temporarily halt moult and migration, in order to do something else, before resuming moult or migration wherever they left off. Some species insert migration or moult between successive bouts of breeding within the same spring-summer season.

2. Such variation is apparent not only between species, but also between different populations of the same species, depending on the locations of their breeding and wintering areas, and the length of journeys they undertake. Some populations have only two components in their annual cycles, breeding and moult, but others have up to seven components, with one or more bouts of breeding, moult and migration. 
3. In general, large birds take longer to breed and moult than small ones, and show greater overlap between these processes. In other words, with increasing body size, we can expect that most birds become more constrained in their timing, and limited in their migration distances (see Hedenström \& Alerstam 1998).

4. In terms of positioning within the annual cycle, breeding normally takes precedence, occurring at the best time of year, but when breeding is omitted or curtailed, moults and migrations can shift to occur within the period otherwise occupied by breeding. Of all the major processes, moult is most variable between species and populations in its positioning within the annual cycle.

5. Although poorly described in physiological terms, it is likely that many bird species can remain in a state of readiness to breed, moult or migrate over longer periods of the year than these processes normally occur. This would account for the observed flexibility in individual cycles, according to specific circumstances at the time, and for the fact that two or more processes can sometimes occur simultaneously.

\section{References}

Aebischer, N. J. \& Potts, G. R. (1994) Quail Coturnix coturnix. Pp. 222-223 in 'Birds in Europe. Their conservation status'. (eds. G. M. Tucker \& M. F. Heath). Cambridge, UK, Birdlife International.

Arendt, W. J., Vargas Mora, T. A. \& Wiley, J. W. (1979) White-crowned Pigeon: status rangewide and in the Dominican Republic. Proc. Conf. S.E. Assoc. Fish Wildl. Agencies 33: 111-122.

Ashmole. N. P. (1963) The biology of the Wideawake or Sooty Tern Sterna fuscata on Ascension Island. Ibis 103b: 297-364.

Bairlein, F. (2003). Nutritional strategies in migratory birds. Pp. 321-332 in 'Avian Migration'. (eds. P. Berthold, E. Gwinner \& E. Sonnenschein). Berlin, SpringerVerlag.

Barta, Z., McNamara, J. M., Houston, A. I., Weber, T. P., Hedenström, A. \& Feró, O. (2008) Optimal moult strategies in migratory birds. Phil Trans R. Soc. 363: 211-229. 
Bensch, S., Hasselquist, D., Hedenström, A. \& Ottosson, U. (1991) Rapid moult among palaearctic passerines in West Africa - an adaptation to the oncoming dry season? Ibis 133: 47-52.

Berthold, P. (1993) Bird migration. A general survey. Oxford, University Press.

Berthold, P. (1996) Control of bird migration. London, Chapman \& Hall.

Bluhm, C. (1988) Temporal patterns of pair formation and reproduction in annual cycles and associated endocrinology in waterfowl. Current Orn. 5: 123-185.

Bojarinova, J., Ilves, A., Chernetsov, N. \& Leivits, A. (2008) Body mass, moult and migration speed of the Goldcrest Regulus regulus in relation to the timing of migration at different sites of the migration route. Ornis Fenn. 85: 55-65.

Branson, N. J. B. A., Ponting, E. D. \& Minton, C. D. T. (1979) Turnstone populations on the Wash. Bird Study 26: 47-54.

Brown, L. H. (1966) Observations on some Kenya eagles. Ibis 108: 531-572.

Bucher, E. H. (1982). Colonial breeding of the Eared Dove (Zenaida auriculata) in northeastern Brazil. Biotropica 14: 255-261.

Buehler, D. M. \& Piersma, T. (2008) Travelling on a budget: predictions and ecological evidence for bottlenecks in the annual cycle of long distance migrants. Phil Trans. R. Soc. B 363: 247-266.

Catry, T., Ramos, J. A., Le Corre, M. \& Phillips, R. A. (2009). Movements, at-sea distribution and behaviour of a tropical pelagic seabird: the Wedge-tailed Shearwater in the western Indian Ocean. Marine Ecol. Prog. Ser. 391: 231-242.

Cramp, S. (1985) Handbook of the Birds of Europe, the Middle East and North Africa, Vol. 4. Oxford, University Press.

Cramp, S. (1988) Handbook of the Birds of Europe, the Middle East and North Africa, Vol. 5. Oxford, University Press. 
Cramp, S. (1992) Handbook of the Birds of Europe, the Middle East and North Africa, Vol. 6. Oxford, University Press.

Cramp, S. \& Perrins, C. M. (1993) Handbook of the Birds of Europe, the Middle East and North Africa, Vol. 7. Oxford, University Press.

Cramp, S. \& Perrins, C. M. (1994a) Handbook of the Birds of Europe, the Middle East and North Africa, Vol. 8. Oxford, University Press.

Cramp, S. \& Perrins, C. M. (1994b) Handbook of the Birds of Europe, the Middle East and North Africa, Vol. 9. Oxford, University Press.

Cramp, S. \& Simmons, K. E. L. (1977). Handbook of the Birds of Europe, the Middle East and North Africa, Vol 1. Oxford, University Press.

Cramp, S. \& Simmons, K. E. L. (1980) Handbook of the Birds of Europe, the Middle East and North Africa, Vol. 2. Oxford, University Press.

Cramp, S. \& Simmons, K. E. L. (1983) Handbook of the Birds of Europe, the Middle East and North Africa, Vol 3. Oxford, University Press.

Dittman, T. \& Becker, P. H. (2003) Sex, age, experience and condition as factors affecting arrival date in prospecting Common Terns, Sterna hirundo. Anim. Behav. 65: 981-986.

Elliott, C. C. H., Waltner, M., Underhill, L. G., Pringle, J. S. \& Dick, W. J. A. (1976) The migration system of the Curlew Sandpiper Calidris ferruginea in Africa. Ostrich 47: 191-213.

Evans, P. R. \& Davidson, N. C. (1990) Migration strategies and tactics of waders breeding in arctic and north temperate latitudes. Pp. 387-398 in 'Bird migration. Physiology and ecophysiology'. (ed. E. Gwinner). Berlin, Springer-Verlag.

Flinks, H., Helm, B. \& Rothery, P. (2008) Plasticity of moult and breeding schedules in migratory European Stonechats Saxicola rubicola. Ibis 150: 687-697. 
Gibbs, H. L. \& Grant, P. R. (1987). Ecological consequences of an exceptionally strong El Niño event on Darwins Finches. Ecology 68: 1735-1746.

Goss-Custard, J. D., Le V. dit. Durell, S. E. A., Sitters, H. P. \& Swinfen, R. (1982) Age-structure and survival of a wintering population of Oystercatchers. Bird Study 29: 83-98.

Götmark, F. (1982) Irruptive breeding of the Redpoll, Carduelis flammea, in south Sweden in 1975. Vår Fågelvärld 41: 315-322

Grubb, T. G., Bowerman, W. W. \& Howey, P. W. (1994) Tracking local and seasonal movements of wintering Bald Eagles Haliaeetus leucocephalus. Pp. 347358 in 'Raptor conservation today'. (eds. B.-U. Meyburg \& R. D. Chancellor). London, Pica Press.

Gill, R. E., Jr., Tibbits, T. L., Douglas, D. C., Handel, C. M., Mulcahy, B. J., Battley, P. F. \& Piersma, T. (2009) Extreme endurance flights by landbirds crossing the Pacific Ocean: ecological corridor rather than barrier? Proc. R. Soc. B. 276: 447-457. Guilford, T. C., Meade, J., Willis, J., Phillips, R. A., Boyle, D., Roberts, S., Collett, M., Freeman, R. \& Perrins, C. M. (2009) Migration and stopover in a small pelagic seabird, the Manx Shearwater Puffinus puffinus: insights from machine learning. Proc. R. Soc. B 276: 1215-1223.

Gwinner, E. (1986) Circannual rhythms. Berlin, Springer.

Halley, D. J., Harris, M. P. \& Wanless, S. (1995) Colony attendance patterns and recruitment in immature Common Murres (Uria aalge). Auk 112: 947-957.

Hamilton, W. J. (1998) Tricolored Blackbird itinerant breeding in California. Condor 100: 218-226.

Hatch, S.A. (1983) Mechanism and ecological significance of sperm storage in the Northern Fulmar with reference to its occurrence in other birds. Auk 100: 593-600. 
Hedenström, A. \& Alerstam, T. (1998) How fast can birds migrate? J. Avian Biol. 29: 424-432.

Helm, B., Gwinner, E. \& Trost, L. (2005) Flexible seasonal timing and migratory behaviour. Results from Stonechat breeding programmes. Ann. N. Y. Acad. Sci. 1046: $216-227$.

Hémon, Y. A., Saint-Jalme, M. \& Guyomarc'h, J. C. (1988). Structure et functtionnement des populations reproductrices 'français' de Cailles des blé. Bull. Mensuel de l'Office National de la Chasse 127: 29-32.

Hockey, P. A. R., Turpie, J. K. \& Velásquez, C. R. (1998) What selective pressures have driven the evolution of deferred northward migration by juvenile waders? J. Avian Biol. 29: 325-330.

Hötker, H. (2002) Arrival of Pied Avocets Recurvirostra avosetta at the breeding site: effects of winter quarters and consequences for reproductive success. Ardea 90: 379387.

Jaeger, M. M., Bruggers, R. L., Johns, B. E. \& Erickson, W. A. (1986) Evidence of itinerant breeding of the Red-billed Quelea Quelea quelea in the Ethiopian Rift Valley. Ibis 128: 469-482.

Jehl, J. R. (1990) Aspects of the moult migration. Pp.102-113 in Bird migration: physiology and ecophysiology (ed. E. Gwinner). Berlin, Springer.

Jenni, L. \& Winkler, R. (1994) Moult and ageing of European passerines. London: Academic Press.

Jones, P. J. (1995) Migration strategies of Palearctic passerines in Africa: an overview. Is. J. Zool. 41: 393-406.

Kjellén, N. (1992) Differential timing of autumn migration between sex and age groups in raptors at Falsterbo, Sweden. Ornis Scand. 23: 420-434. 
Kjellén, N. (1994) Moult in relation to migration in birds - a review. Ornis Svecica 4: $1-24$.

Koford, C. B. (1953) The California Condor. Nat. Audubon Soc. Res. Rep. 4: 1-154

Lack, D. (1954) The natural regulation of animal numbers. Oxford, University Press.

Ligon, J. D. (1971) Late summer-autumnal breeding of the Pinyon Jay in New Mexico. Condor 73: 147-153.

Lloyd, C. S. \& Perrins, C. M. (1977) Survival and age at first breeding in the Razorbill (Alca torda). Bird Banding 48: 239-252.

McNamara, J. M. (2008) J. M. \& Houston, A. I. (2008) Optimal annual routines: behaviour in the context of physiology and ecology. Phil. Trans. R. Soc. 363: 301319.

McNeil, R., Diaz, M. T. \& Villeneuve, A. (1994) The mystery of shorebird oversummering: a new hypothesis. Ardea 82: 143-152.

Meltofte, H. (1996) Are African wintering waders really forced south by competition from northerly wintering conspecifics? Benefits and constraints of northern versus southern wintering and breeding in waders. Ardea 84: 31-44.

Metcalfe, N. B. \& Furness, R. W. (1985) Survival, winter population stability and site-fidelity in the Turnstone Arenaria interpres . Bird Study 32: 207-214.

Meyburg, B.-U., Scheller, W. \& Meyburg, C. (1995) Migration and wintering of the Lesser Spotted Eagle (Aquila pomarina) - a study by means of satellite telemetry. J. Ornithol. 136: 401-422.

Meyburg, B.-U. \& Meyburg, C. (1999) The study of raptor migration in the Old World using satellite telemetry. Proc. Int. Orn. Congr. 22: 2992-3006. 
Meyburg, B.-U., Meyburg, C., Bělka, T., Šreibr, O. \& Vrana, J. (2004) Migration, wintering and breeding of a Lesser Spotted Eagle (Aquila pomarina) from Slovakia tracked by satellite. J. Ornithol. 145: 1-7.

Miller, A. H. (1954. Breeding cycles in a constant equatorial environment in Columbia, South America. Proc Int. Orn. Cong. 11: 495-503.

Miller, A. H. (1959) Reproductive cycles in an equatorial sparrow. Proc. Nat. Acad. Sci. 45: 1075-1100.

Moreau, R. E. (1951) The British status of the Quail and some problems of its biology. Brit. Birds 44: 257-276.

Murphy, M. (1999) Energetics and nutrition of moulting. In: Adams, N. J. \& Slotow, R. H. (eds) proc. 22 Int. Orn. Congr., Durban: 527-535. Johannesburg: Birdlife South Africa.

Murton, R. K. \& Westwood, N. J. (1977) Avian Breeding Cycles. Oxford, Clarendon Press.

Myers, J. P. (1981). A test of three hypotheses for latitudinal segregation of the sexes in wintering birds. Can. J. Zool. 59: 1527-1534.

Newton, I. (1972) Finches. London, Collins.

Newton, I. (1999) An alternative approach to the measurement of seasonal trends in bird breeding success: a case study of the Bullfinch Pyrrhula pyrrhula. J. Anim. Ecol. 68: 698-707.

Newton, I. (2007. Weather-related mass-mortality events in migrants. Ibis 149: 453467.

Newton, I. (2008) The migration ecology of birds. London: Academic Press.

Newton, I., \& Marquiss, M. (1982) Moult in the Sparrowhawk. Ardea 70: 163-172. 
Newton, I. \& Rothery, P. (2005). The timing, duration and pattern of moult and its relationship to breeding in a population of the European Greenfinch Carduelis chloris. Ibis 147: 667-679.

Noskov, G. A., Rymkevich, T. A. \& Iovchenko, N. P. (1999) Intraspecific variation of moult: adaptive significance and ways of realisation. In: Adams, N. J. \& Slotow, R. H. (eds) proc. 22 Int. Orn. Congr., Durban: 544-563. Johannesburg: Birdlife South Africa.

Oring, L. W. \& Lank, D. B. (1982). Sexual selection, arrival times, philopatry and site fidelity in the polyandrous Spotted Sandpiper. Behav. Ecol. Sociobiol. 10: 185191.

Payevsky, V. A. (1994). Age and sex structure, mortality and spatial winter distribution of Siskins (Carduelis spinus) migrating through eastern Baltic area. Die Vogelwarte 37: 190-198.

Payne, R. B. (1969) Breeding seasons and reproductive physiology of Tricolored Blackbirds and Red-winged Blackbirds. Univ. Calif. Publ. Zool. 90: 1-115.

Peiponen, V. A. (1967) Südliche Fortpflanzung und Zug von Carduelis flammea (L.) in Jahre 1965. Ann. Zool. fenn. 4: 547-549.

Perrins, C. M. \& Brooke M. de L. (1976) Manx Shearwaters in the Bay of Biscay. Bird Study 23: 295-300.

Perrins, C. M, Harris, M. P. \& Britton, C. K. (1973) Survival of Manx Shearwaters Puffinus puffinus. Ibis 115: 535-548.

Phillips, R. A., Catry, P., Silk, J. R. D., Bearhop, S., McGill, R., Afanasyev, V. \& Strange, I. J. (2007). Movements, winter distribution and activity patterns of Falkland and Brown Skuas: insights from loggers and isotopes. Marine Ecol. Prog. Ser. 345: $281-291$ 
Phillips, R. A., Silk, J. R. D., Croxall, J. P. \& Afanasyev, V. (2006). Year-round distribution of White-chinned Petrels from South Georgia: relationships with oceanography and fisheries. Biol. Conserv. 129: 336-347.

Pulido, F. \& Berthold, P. (2003) Quantitative genetic analyses of migratory behaviour. Pp. 53-77 in 'Avian Migration'. (eds. P. Berthold, E. Gwinner \& E. Sonnenschein). Berlin, Springer-Verlag.

Rogers, D. T. (2006) Hidden costs: challenges faced by migratory shorebirds living on intertidal flats., PhD thesis, Charles Sturt University, Australia.

Rohwer, S. (1999) Time constraints and moult-breeding tradeoffs in large birds. In: Adams, N. J. \& Slotow, R. H. (eds) proc. 22 Int. Orn. Congr., Durban: 568-581. Johannesburg: Birdlife South Africa.

Rohwer, S., Hobson, K. A. \& Rohwer, V. G. (2009) Migratory double breeding in Neotropical migrant birds. PNAS 106: 19050-19055.

Salomonsen, F. (1968). The moult migration. Wildfowl 19: 5-24.

Schreiber, E. A. \& Burger, J. (2002). Biology of marine birds. New York, CPR Press. Schwabl, H. (1983) Ausprägung und Bedeutung des Teilzugverhaltens einer sudwestdeutschen Population der Amsel Turdus merula. J. Ornithol. 124: 101-115.

Serra, L. (1998) The adaptation of primary moult to migration and wintering in the Grey Plover (Pluvialis squatarola): a preliminary outlook. Biol. Conserv. Fauna 102:123-127.

Serra, L. (2000) How do Palaearctic Grey Plovers adapt primary moult to time constraints? An overview across four continents. Wader study Group Bull. 93:11-12.

Shaffer, S. A., Tremblay, Y.,Weimerskirsch, H., Scott, D., Thompson, D. R., Sagar, P. M., Moller, H., Taylor, G. A., Foley, D. G., Block, B. A. \& Costa, D. P. (2006) 
Migratory shearwaters integrate oceanic resources across the Pacific Ocean in an endless summer. PNAS 1103: 2799-2802.

Shirihai, H., Yosef, R., Alon, D., Kirwan, G. M. \& Spaar, R. (2000). Raptor migration in Israel and the Middle East. A summary of 30 years of field research. Israel, International Birding \& Research Centre.

Smith, H. G. \& Nilsson, J.-A. 1987 Intraspecific variation in migratory pattern of a partial migrant, the Blue Tit (Parus caeruleus): an evaluation of different hypotheses. Auk 104: 109-115.

Snow, D. W. (1962) A field study of the Black-and-White Manakin, Manacus manacus, in Trinidad. Zoologica 47: 65-104.

Snow, D. W. (1965) The breeding od Audubon's Shearwater (Puffinus lherminieri) in the Galapagos. Auk 82: 591-597.

Sohle, L. S., Robertson, C. J. R., Nicholls, D. G., Mouritsen, H., Frost, B. \& Moller, H. 2007. Satellite tracking of Sooty SDhearwaters (Puffinus griseus) during their prelaying exodus and incubation. Notornis 54: 180-188.

Stresemann, E \& Stresemann, V. (1966) Die Mauser der Vögel. J. Orn. 107: 3-448. Summers, R. W., Underhill, L. G. \& Prys-Jones, R. P. (1995) Why do young waders in southern Africa delay their first return migration to the breeding grounds? Ardea 83: $351-357$

Thomson, C. W. (1991) The sequence of moults and plumages in Painted Buntings and implications for theories of delayed plumage maturation. Condor 93: 209-235.

Underhill, L G. (2003. Within ten feathers: primary moult strategies of migratory waders (Charadrii). Pp. 187-197 in Avian Migration, et. P. Berthold, E. Gwinner \& E. Sonnenschein. Berlin: Springer-Verlag.

Ward, P. (1971) The migration patterns of Quelea quelea in Africa. Ibis 113: 275-297. 
Ward, P. \& Jones, P. J. (1977). Pre-migratory fattening in three races of the Redbilled Quelea Quelea quelea (Aves: Ploceidae), an intra-tropical migrant. J. Zool. Lond. 181: 43-56.

Warham, J. (1990) The Petrels. Their ecology and breeding systems. London, Academic Press.

Whitfield, D. P. 2002 Dotterel. Pp.281-283 in Wernham, C. V., Toms, M. P., Marchant, J. H., Clark, J. A., Siriwardena, G. M. \& Baillie, S. R. (2002) The migration atlas: movements of the birds of Britain and Ireland. London, T \& A.D. Poyser.

Willoughby, E. J. (2004) Molt and plumage terminology of Howell et al. (2003) still may not reflect homologies. Condor 106: 191-196.

Wingfield, J. C. (2005) Flexibility in annual cycles of birds: implications for endocrine control mechanisms. J. Ornithol. 146: 291-304.

Wingfield, J. C. (2008) Organisation of vertebrate annual cycles: implications for control mechanisms. Phil. Trans. R. Scoc. B 363: 425-441.

Wyllie, I. (1981) The Cuckoo. London, Batsford.

Zann, R. A., Morton, S. R., Jones, K. R. \& Burley, N. T. (1995) The timing of breeding by Zebra Finches in relation to rainfall in central Australia. Emu 95: 208222. 
Table 1. Data on the pre-laying exodus of petrels and shearwaters studied using tracking devices. PTT - platform transmitter terminals, GLS global location sensors (or geolocators).

White-chinned Petrel Procellaria aequinoctialis, South Georgia, nine birds studied using GLS. On pre-laying exodus of 2-3 weeks, mainly to the Patagonian Shelf to the northwest, birds extended to a mean maximum distance of 2,180 km from the colony, involving a cumulative travel distance of $6,360 \mathrm{~km}$. Trips during incubation were shorter in time and distance, but comparable in maximum range and travel speed. Trips during chick-feeding were shorter still, and extended less far from the colony (Phillips et al. 2006).

Manx Shearwater Puffinus puffinus, Skomer Island off Wales, 12 birds studied using GLS. Most males remained within a few hundred km of the colony, while females moved mainly southwest to the shelf edge, up to $1,200 \mathrm{~km}$ from the colony. They were away for an average of 20 days (Guilford et al. 2009).

Wedge-tailed Shearwater Puffinus pacificus, Aride Island, southern Indian Ocean, studied using GLS. Thirteen birds foraged within 1,000 km of the colony, but three others flew far to the northwest, one female covering a total of 7,000 km in 22 days (Catry et al. 2009).

Sooty Shearwater Puffinus griseus, Taiaroa Head, New Zealand, three birds studied using PTTs. Two males flew up to $1,800 \mathrm{~km}$ and $500 \mathrm{~km}$ from the colony, one female up to $1,300 \mathrm{~km}$. The total distances flown were $7,700 \mathrm{~km}$ in 34 days, 4,200 in 28 days, and 3,700 $\mathrm{km}$ in 16 days respectively. In this species, even greater distances were recorded during chick feeding (Söhle et al. 2007). 


\section{Captions}

Figure 1. Major variants in the annual cycles of birds. Examples of species which show each pattern are for Sequence 1: Common Redpoll Carduelis flammea, Robin Erithaca rubecula; Sequence 2: Yellow-breasted Bunting (nominate race) Emberiza aureola, Northern Lapwing Vanellus vanellus; Sequence 3: Scarlet Rosefinch Carpodacus erythrinus, Swift Apus apus; Sequence 4: Bee-eater Merops apiaster, Osprey Pandion haliaetus; Sequence 5: Marsh Warbler Acrocephalus palustris, Kentish Plover Charadrius alexandrinus, Spotted Redshank Tringa erythropus; sequence 6: Wilson's Phalarope Phalaropus tricolor, Spotted Sandpiper Actitis macularia, and other populations of shorebirds; Sequence 7: Willow Warbler Phylloscopus trochilus, Whinchat Saxicola rubetra; Sequence 8: Lanceolated Warbler Locustella lanceolata, some populations of Curlew Sandpiper Calidris ferruginea, Red Knot Calidris canutus and other shorebirds. 

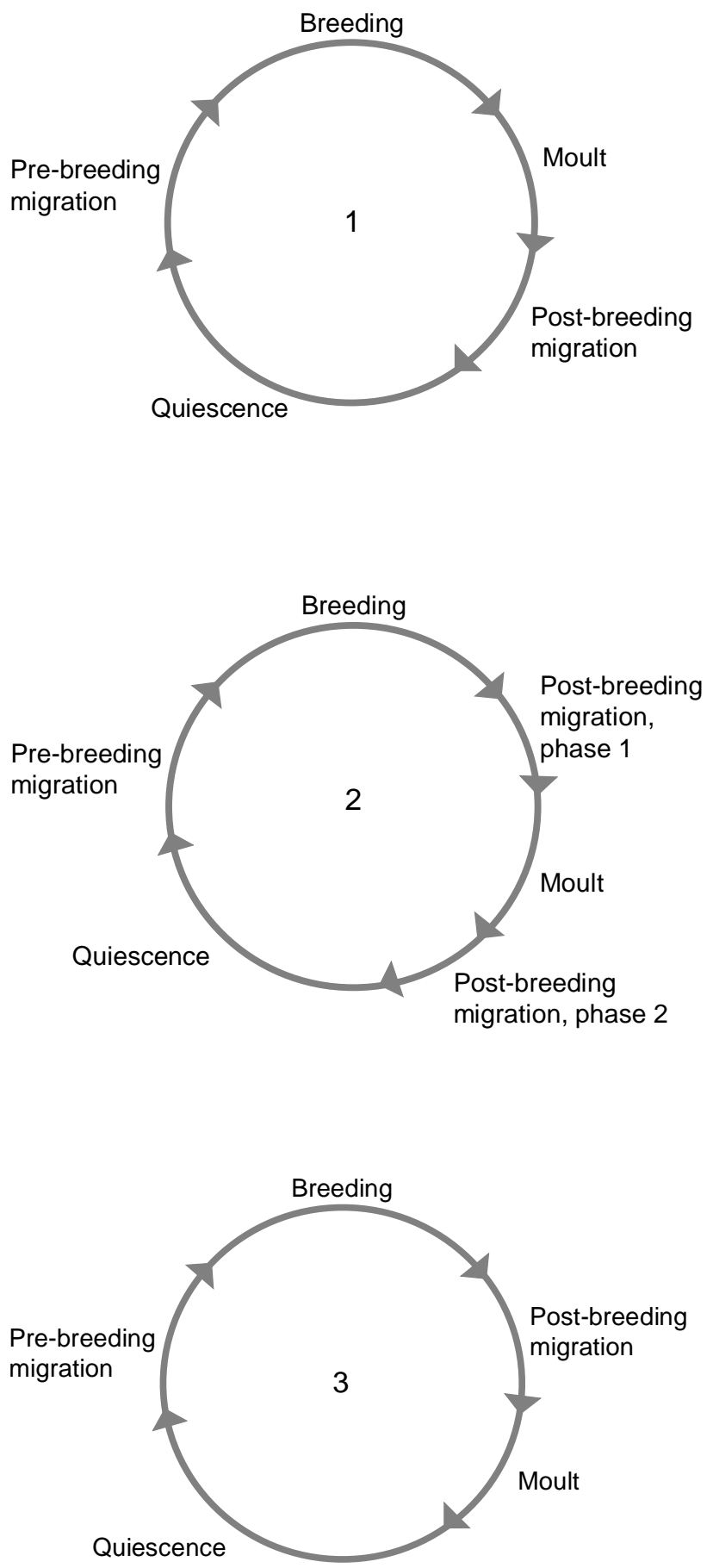

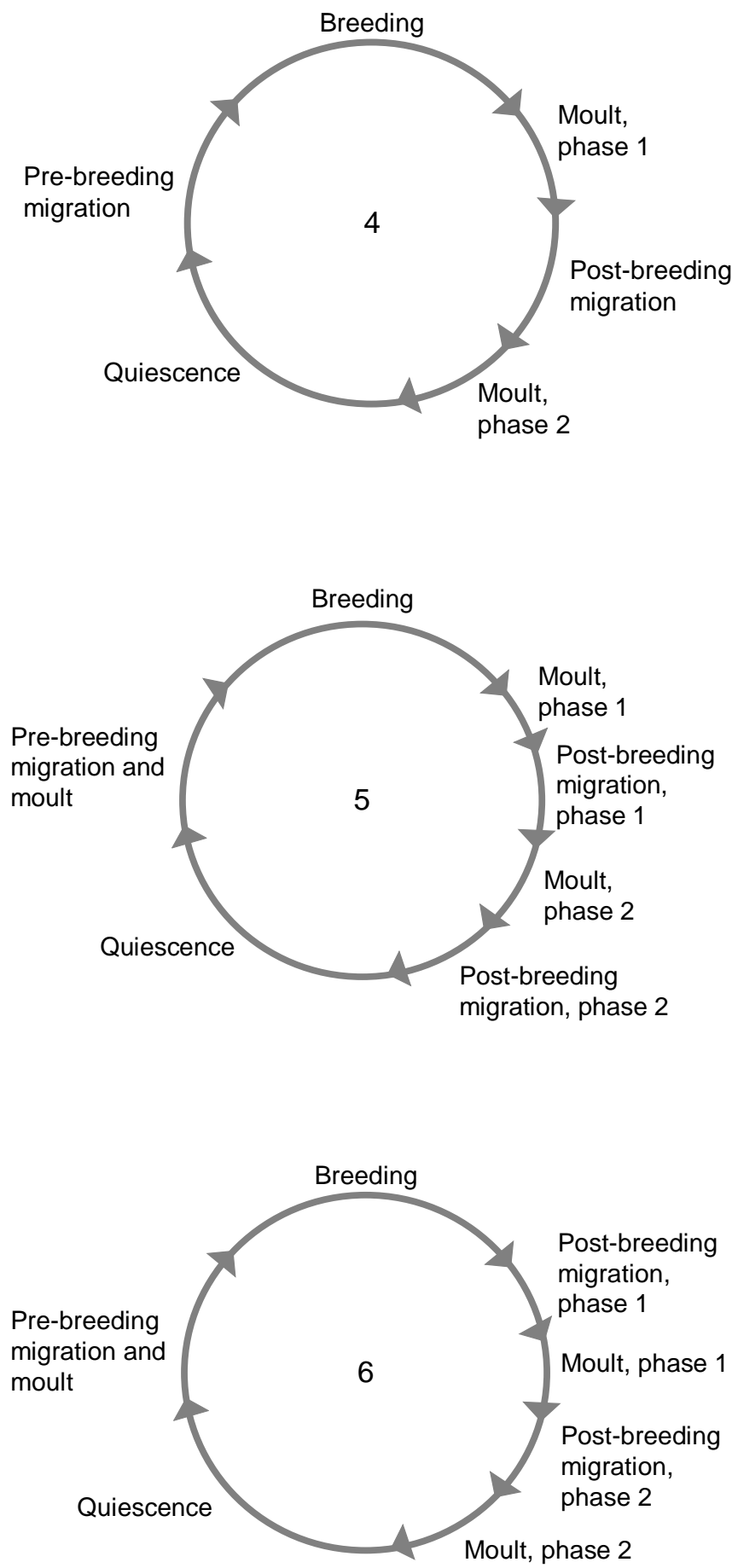

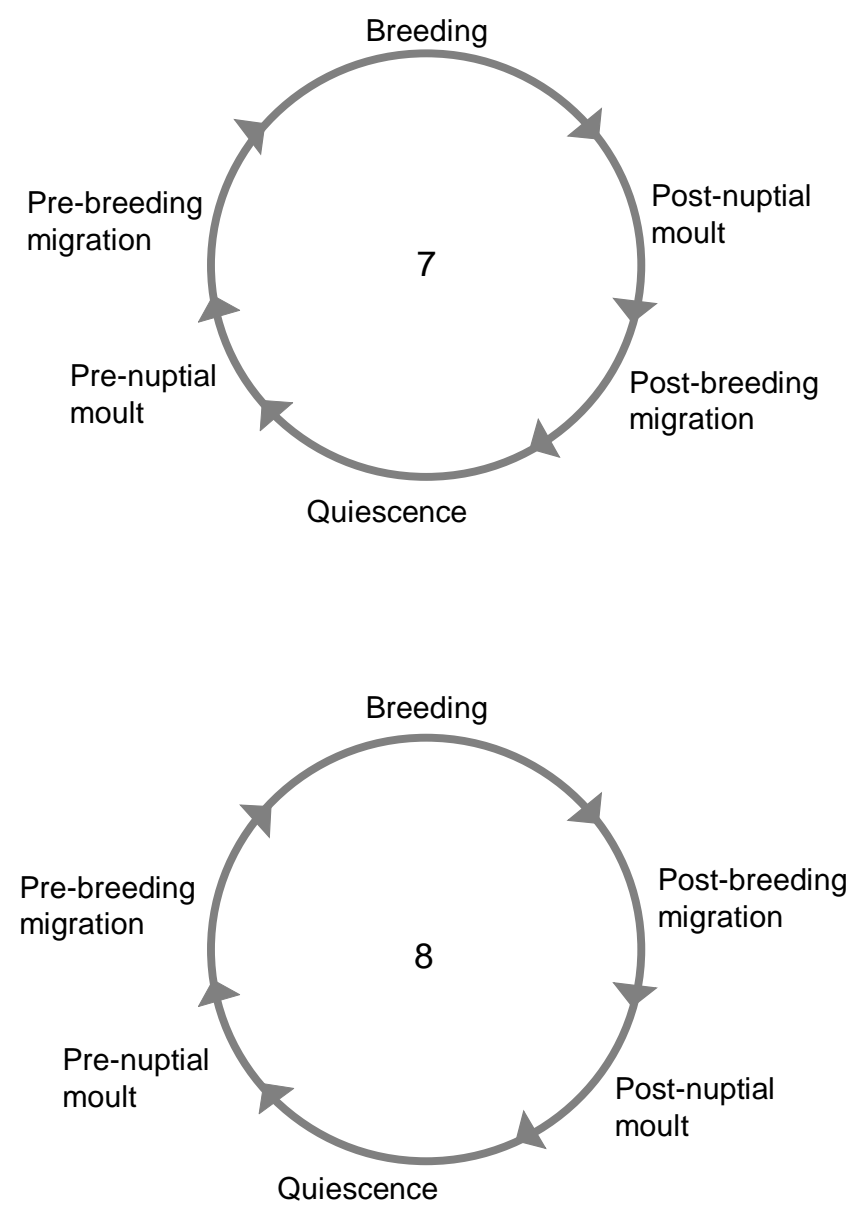
